\title{
Behaviour of gaseous chlorine and alkali metals during biomass thermal utilisation
}

\author{
Xiaolin Wei ${ }^{\mathrm{a}}$, Uwe Schnell ${ }^{\mathrm{b}, *}$, Klaus R.G. Hein ${ }^{\mathrm{b}}$ \\ ${ }^{a}$ Institute of Mechanics, Chinese Academy of Sciences (CAS), Bei Si Huan Xi Lu.15, Beijing 100080, People's Republic of China \\ ${ }^{\mathrm{b}}$ Institute of Process Engineering and Power Plant Technology (IVD), University of Stuttgart, Pfaffenwaldring 23, D-70569 Stuttgart, Germany
}

Received 26 August 2004; received in revised form 30 November 2004; accepted 30 November 2004

Available online 15 December 2004

\begin{abstract}
The behaviour of gaseous chlorine and alkali metals of three sorts of biomass (Danish straw, Swedish wood, and sewage sludge) in combustion or gasification is investigated by the chemical equilibrium calculating tool. The ranges of temperature, air-to-fuel ratio, and pressure are varied widely in the calculations $(T=400-1800 \mathrm{~K}, \lambda=0-1.8$, and $P=0.1-2.0 \mathrm{MPa})$. Results show that the air excess coefficient only has less significant influence on the release of gaseous chlorine and potassium or sodium during combustion. However, in biomass gasification, the influence of the air excess coefficient is very significant. Increasing air excess coefficient enhances the release of $\mathrm{HCl}(\mathrm{g})$, $\mathrm{KOH}(\mathrm{g})$, or $\mathrm{NaOH}(\mathrm{g})$ as well as it reduces the formation of $\mathrm{KCl}(\mathrm{g}), \mathrm{NaCl}(\mathrm{g}), \mathrm{K}(\mathrm{g})$, or $\mathrm{Na}(\mathrm{g})$. In biomass combustion or straw and sludge gasification, increasing pressure enhances the release of $\mathrm{HCl}(\mathrm{g})$ and reduces the amount of $\mathrm{KCl}(\mathrm{g}), \mathrm{NaCl}(\mathrm{g}), \mathrm{KCl}(\mathrm{g})$, or $\mathrm{NaOH}(\mathrm{g})$ at high temperatures. However, during wood gasification, the pressure enhances the formation of $\mathrm{KOH}(\mathrm{g})$ and $\mathrm{KCl}(\mathrm{g})$ and reduces the release of $\mathrm{K}(\mathrm{g})$ and $\mathrm{HCl}(\mathrm{g})$ at high temperatures. During wood and sewage sludge pyrolysis, nitrogen addition enhances the formation of $\mathrm{KCN}(\mathrm{g})$ and $\mathrm{NaCN}(\mathrm{g})$ and reduces the release of $\mathrm{K}(\mathrm{g})$ and $\mathrm{Na}(\mathrm{g})$. Kaolin addition in straw combustion may enhance the formation of potassium aluminosilicate in ash and significantly reduces the release of $\mathrm{KCl}(\mathrm{g})$ and $\mathrm{KOH}(\mathrm{g})$ and increases the formation of $\mathrm{HCl}(\mathrm{g})$.

(C) 2004 Elsevier Ltd. All rights reserved.
\end{abstract}

\section{Introduction}

The thermal utilisation of biomass can contribute to the reduction of $\mathrm{CO}_{2}$ emissions. Compared with coal, biomass has a high amount of potassium, chlorine, and silicon as well as minor amounts of $\mathrm{Ca}, \mathrm{Mg}, \mathrm{Al}, \mathrm{Fe}, \mathrm{Na}$, and $\mathrm{S}$, etc. During combustion or gasification (i.e. air-fuel ratio $\lambda>1$ or $<1$ ) of biomass, significant amounts of chlorine and alkali metals are released into the gas phase, such as $\mathrm{HCl}(\mathrm{g}), \mathrm{KCl}(\mathrm{g})$, $\mathrm{KOH}(\mathrm{g})$, and $\mathrm{NaCl}(\mathrm{g})$, etc. They are very harmful in terms of causing fouling, slagging, and high temperature corrosion in the furnace [1-10]. For direct fired combined cycles, the alkali species in the gas phase can result in serious corrosive problems at gas turbines [11-13]. Hydrogen chloride may

\footnotetext{
* Corresponding author. Tel.: +49 711685 3574; fax: +49 711685 3491.

E-mail addresses: xlwei@imech.ac.cn (X. Wei), schnell@ivd.unistuttgart.de (U. Schnell).
}

also tend to produce unacceptably high emissions of $\mathrm{HCl}$ and dioxins [14-20]. In addition, $\mathrm{HCl}, \mathrm{SO}_{2}$, and released alkali species are likely to form aerosols in the flue gas [13,21-23].

It is found that the major ash forming elements $(\mathrm{Al}, \mathrm{Si})$ and the composition of gas phase $\left(\mathrm{O}_{2}, \mathrm{~N}_{2}\right.$, and $\mathrm{H}_{2} \mathrm{O}$, etc.) have significant influence on the behaviour of chlorine and alkali metals [24-31]. In fact, it may be affected by many factors, such as composition of the fuel, combustion or gasification conditions, and low or high pressure. However, few studies have been carried out to analyse the influence of fuel minerals on this behaviour considering all of the mineral elements (Al, Si, K, Na, Ca, Mg, Fe, Ti, Mn, S, Cl, and $\mathrm{P}$, etc.). In addition, there are very limited results in this field for biomass gasification under pressurized conditions.

The aim of this work is to investigate the release of chlorine and alkali metals for three kinds of biomass during combustion or gasification under pressurized conditions by the equilibrium calculating tool FactSage (Table 1 shows 
Table 1

Pulverized biofuel composition

\begin{tabular}{|c|c|c|c|c|c|c|c|}
\hline $\begin{array}{l}\text { Chemical analysis } \\
(\%)\end{array}$ & Danish straw & Swedish wood & Sewage sludge & $\begin{array}{l}\text { Ash analysis } \\
(\%) \text { dry }\end{array}$ & Danish straw & Swedish wood & Sewage sludge \\
\hline Moisture & 11.71 & 7.80 & 5.86 & $\mathrm{Al}_{2} \mathrm{O}_{3}$ & 0.36 & 4.69 & 10.34 \\
\hline Volatile dry & 71.32 & 84.10 & 48.45 & $\mathrm{CaO}$ & 4.34 & 30.49 & 16.04 \\
\hline Ash dry & 13.42 & 0.20 & 48.06 & $\mathrm{Fe}_{2} \mathrm{O}_{3}$ & 0.26 & 2.67 & 17.83 \\
\hline Fixed C dry & 15.26 & 15.70 & 3.65 & $\mathrm{~K}_{2} \mathrm{O}$ & 14.79 & 9.46 & 0.93 \\
\hline C dry & 41.43 & 49.57 & 25.77 & $\mathrm{MgO}$ & 0.87 & 5.93 & 2.05 \\
\hline $\mathrm{N}$ dry & 1.09 & 0.07 & 3.02 & $\mathrm{Na}_{2} \mathrm{O}$ & 0.35 & 2.10 & 2.16 \\
\hline S dry & 0.10 & 0.06 & 0.81 & $\mathrm{SiO}_{2}$ & 68.59 & 18.90 & 26.52 \\
\hline H dry & 4.18 & 6.05 & 4.31 & $\mathrm{SO}_{3}$ & 1.93 & 4.04 & 2.83 \\
\hline $\mathrm{O}$ (diff.) dry & 39.25 & 44.04 & 17.99 & $\mathrm{TiO}_{2}$ & 0.02 & 0.98 & 0.75 \\
\hline $\mathrm{Cl}$ dry & 0.53 & 0.01 & 0.04 & $\mathrm{P}_{2} \mathrm{O}_{5}$ & 1.93 & 2.37 & 15.40 \\
\hline LHV $(\mathrm{MJ} / \mathrm{kg})$ dry & 16.01 & 18.52 & 10.72 & $\mathrm{MnO}_{2}$ & $0.02^{\mathrm{a}}$ & 4.61 & $0.02^{\mathrm{a}}$ \\
\hline
\end{tabular}

${ }^{\text {a }}$ Data estimated.

the composition of biomass). The ranges of temperature, air-fuel ratio, and pressure are varied widely, e.g. $T=$ 400-1800 K, $\lambda=0-1.8$, and $P=0.1-2.0 \mathrm{MPa}$.

\section{Calculating method}

The equilibrium analysis software FactSage was used to determine thermodynamic stable chemical and physical forms in the chemical system. When the parameters, such as the elementary composition of the fuel and air, temperature and pressure have been entered, FactSage will search the species including these elements from the database. In this paper, 611 species (143 gas, 94 liquid, and 374 solid species) are selected to conduct the thermodynamic equilibrium calculation for the chemical system including the elements C, H, O, N, S, Cl, Si, P, Ca, K, Na, Mg, Al, Fe, $\mathrm{Ti}$, and $\mathrm{Mn}$ between 800 and $1800 \mathrm{~K}$. Table 2 gives the moles of biomass composition based on $1000 \mathrm{~kg}$ fuels for equilibrium calculation.

Although the equilibrium analysis is a powerful tool to predict the stable species during the chemical process, there are some disadvantages of this method applied to the combustion case [32]. Either the temperature must be high enough or the species residence time should be long enough to reach the thermodynamic equilibrium. The difficulty will arise when the results of the equilibrium calculation are compared with those of real combustion systems. In general, the chemical equilibrium analysis may be used to give the equilibrium distribution of elements and the reaction mechanism of various species.

\section{Results and discussion}

Fig. 1 describes the transformation of alkali metals (e.g. potassium) during biomass thermal utilisation. In biomass gasification or combustion, some of potassium and chlorine will be released into gas, such as $\mathrm{HCl}(\mathrm{g}), \mathrm{KCl}(\mathrm{g}),(\mathrm{KCl})_{2}(\mathrm{~g})$,
$\mathrm{K}_{2} \mathrm{SO}_{4}(\mathrm{~g}), \mathrm{KOH}(\mathrm{g})$, and $\mathrm{K}(\mathrm{g})$, etc. And the others may be retained in ash, forming potassium silicate, aluminosilicate or sulphate. During the cooling process, the gaseous potassium may condense on the coarse fly ash as $\mathrm{KCl}(\mathrm{s})$ or $\mathrm{K}_{2} \mathrm{SO}_{4}(\mathrm{~s})$. Some of gaseous potassium directly forms aerosols or fine fly ash because of condensation, sulfation and carbonization. A part of these aerosols may also attach on the coarse fly ash. The enrichment of potassium, sulphur and chlorine in ash is very harmful because of causing fouling, slagging, and high temperature corrosion in the furnace. In addition, if aerosols are not collected in the ash separator, they may cause air pollution.

Fig. 2 shows the equilibrium results of potassium behaviour for Danish straw and Swedish wood combustion. At high temperatures $(>1100 \mathrm{~K})$, the main potassium containing species are $\mathrm{K}_{2} \mathrm{Si}_{4} \mathrm{O}_{9}(\mathrm{liq}), \mathrm{KCl}(\mathrm{g})$, and $\mathrm{KOH}(\mathrm{g})$ for straw combustion, and $\mathrm{KCl}(\mathrm{g}), \mathrm{K}_{2} \mathrm{SO}_{4}(\mathrm{~g})$, and $\mathrm{KOH}(\mathrm{g})$ for wood combustion. Because of the higher content of

Table 2

Moles of biomass composition based on $1000 \mathrm{~kg}$ fuels $(\lambda=0)$

\begin{tabular}{lccc}
\hline Fuels & Danish straw & Swedish wood & Sewage sludge \\
\hline Main elements & & & \\
$\mathrm{C}$ & 30,457 & 38,055 & 20,200 \\
$\mathrm{H}$ & 49,612 & 63,997 & 46,758 \\
$\mathrm{O}$ & 30,737 & 29,737 & 24,335 \\
$\mathrm{~N}$ & 686.91 & 46.07 & 2029.30 \\
$\mathrm{~S}$ & 27.54 & 17.26 & 237.85 \\
$\mathrm{Cl}$ & 132.00 & 2.60 & 10.62 \\
Minor elements & & & \\
$\mathrm{Si}$ & 1194.10 & 5.35 & 1879.80 \\
$\mathrm{P}$ & 28.45 & 0.57 & 924.20 \\
$\mathrm{Ca}$ & 80.96 & 9.24 & 1218.20 \\
$\mathrm{~K}$ & 328.49 & 3.41 & 84.10 \\
$\mathrm{Na}$ & 11.81 & 1.15 & 296.87 \\
$\mathrm{Mg}$ & 22.58 & 2.50 & 216.61 \\
$\mathrm{Al}$ & 7.39 & 1.56 & 863.88 \\
$\mathrm{Fe}$ & 3.41 & 0.57 & 951.06 \\
$\mathrm{Ti}$ & 0.26 & 0.21 & 39.98 \\
$\mathrm{Mn}$ & 1.90 & 1.43 & 7.75 \\
\hline
\end{tabular}




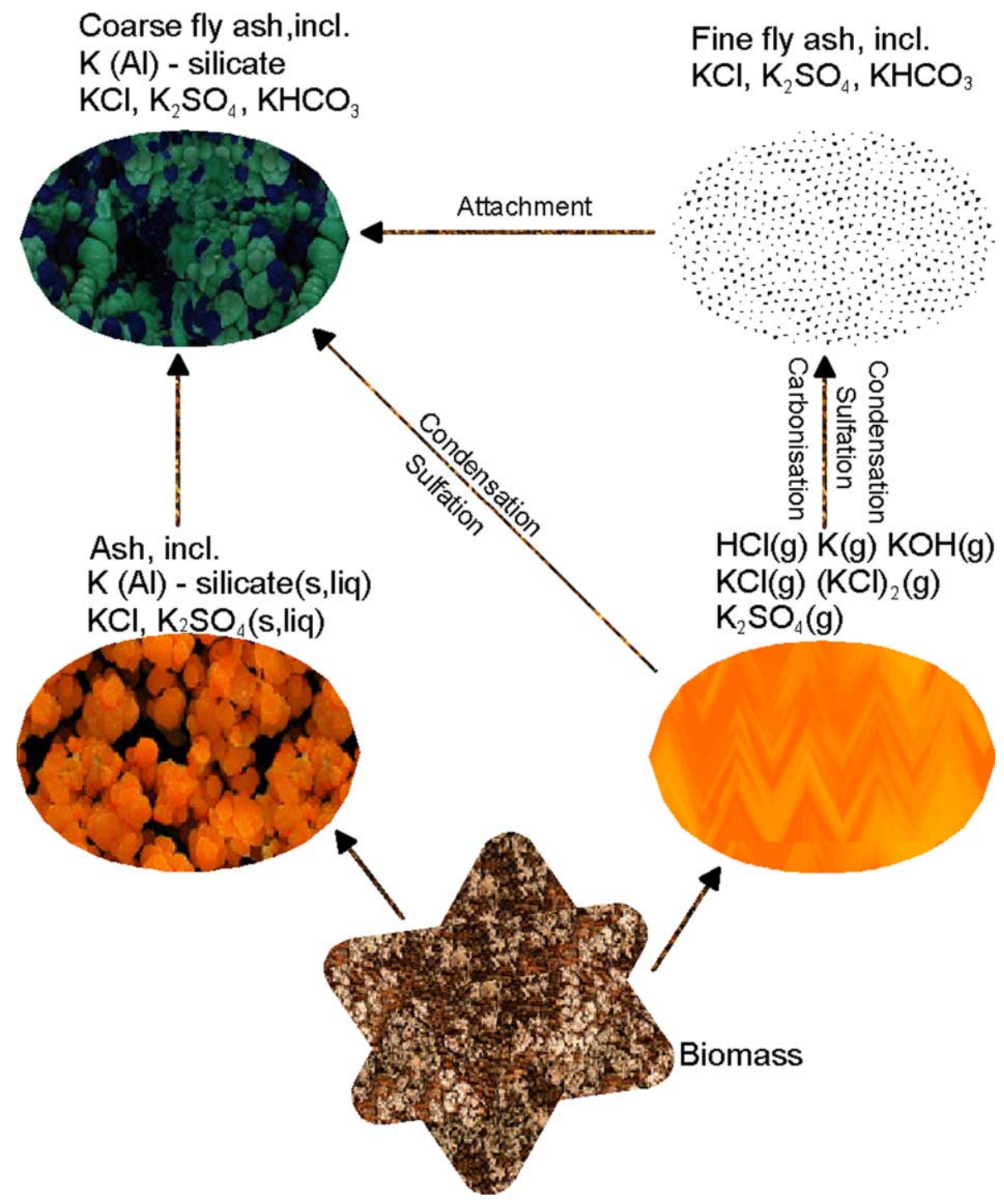

Fig. 1. Transformation of potassium in biomass thermal utilization.

silicon in straw, a higher amount of $\mathrm{K}_{2} \mathrm{Si}_{4} \mathrm{O}_{9}(\mathrm{liq})$ is formed, which may cause slagging and fouling in the furnace. The gaseous potassium species, e.g. $\mathrm{KCl}(\mathrm{g})$ and $\mathrm{KOH}(\mathrm{g})$, may form aerosols in the gas cooling process. At midtemperatures (800-1100 K), the main species are potassium silicate and sulphate (i.e. $\mathrm{K}_{2} \mathrm{Si}_{4} \mathrm{O}_{9}\left(\mathrm{~s}, \mathrm{~s}_{2}\right)$ and $\mathrm{K}_{2} \mathrm{SO}_{4}\left(\mathrm{~s}_{2}\right)$ ) for straw combustion. Obviously, $\mathrm{K}_{2} \mathrm{Si}_{4} \mathrm{O}_{9}\left(\mathrm{~s}, \mathrm{~s}_{2}\right)$ is transformed by the liquid silicate $\mathrm{K}_{2} \mathrm{Si}_{4} \mathrm{O}_{9}$ (liq) under high temperature. For wood combustion, the main species are potassium aluminosilicate and sulphate (i.e. $\mathrm{KAlSi}_{2} \mathrm{O}_{6}\left(\mathrm{~s}, \mathrm{~s}_{2}\right)$ and $\mathrm{K}_{2} \mathrm{SO}_{4}\left(\mathrm{~s}_{2}\right)$ ). At low temperatures (400-900 K), the main species are potassium chloride and sulphate (i.e. $\mathrm{KCl}(\mathrm{s})$, $\mathrm{K}_{2} \mathrm{SO}_{4}(\mathrm{~s})$, and $\mathrm{K}_{2} \mathrm{Si}_{2} \mathrm{O}_{5}(\mathrm{~s})$ ) for straw combustion. Because of the higher content of chlorine than sulphur in straw, a higher amount of chloride is formed than sulphate. For wood combustion, the main species are $\mathrm{K}_{2} \mathrm{SO}_{4}(\mathrm{~s})$ and $\mathrm{KAl}\left(\mathrm{SO}_{4}\right)_{2}(\mathrm{~s})$. Because of the relatively higher content of sulphur than chlorine in wood, potassium sulphate and aluminosilicate becomes important in ash.
Fig. 3 gives the release behaviour of chlorine and alkali metals in combustion with various air excess coefficients. For straw combustion in Fig. 3(a), increasing temperature from 800 to $1000 \mathrm{~K}$ significantly increases the amount of released $\mathrm{HCl}(\mathrm{g})$. This indicates that the gaseous $\mathrm{HCl}$ concentration attains maximum at $1000 \mathrm{~K}$. The reason of this might be that most of chlorine in gaseous $\mathrm{HCl}$ comes from decomposing $\mathrm{KCl}(\mathrm{s})$ in the mid-temperature range. Then increasing temperature from 1000 to $1800 \mathrm{~K}$ reduces the amount of released $\mathrm{HCl}(\mathrm{g})$, thereby $\mathrm{KCl}(\mathrm{g})$ begins to form and gradually increases. At high temperatures ( $>$ $1400 \mathrm{~K})$, a small amount of $\mathrm{KOH}(\mathrm{g})$ also occurs.

For wood combustion in Fig. 3(b), all of the chlorine is released as $\mathrm{HCl}(\mathrm{g})$ in the temperature range of 800-1000 K. With increasing temperature, $\mathrm{KCl}(\mathrm{g})$ and $\mathrm{K}_{2} \mathrm{SO}_{4}(\mathrm{~g})$ begins to form and causes $\mathrm{HCl}(\mathrm{g})$ to decrease. At $1350 \mathrm{~K}, \mathrm{KCl}(\mathrm{g})$ attains maximum and $\mathrm{HCl}(\mathrm{g})$ attains minimum. In addition, from $1200 \mathrm{~K}$, the release of $\mathrm{KOH}(\mathrm{g})$ significantly increases. Because of the low content of chlorine in wood 

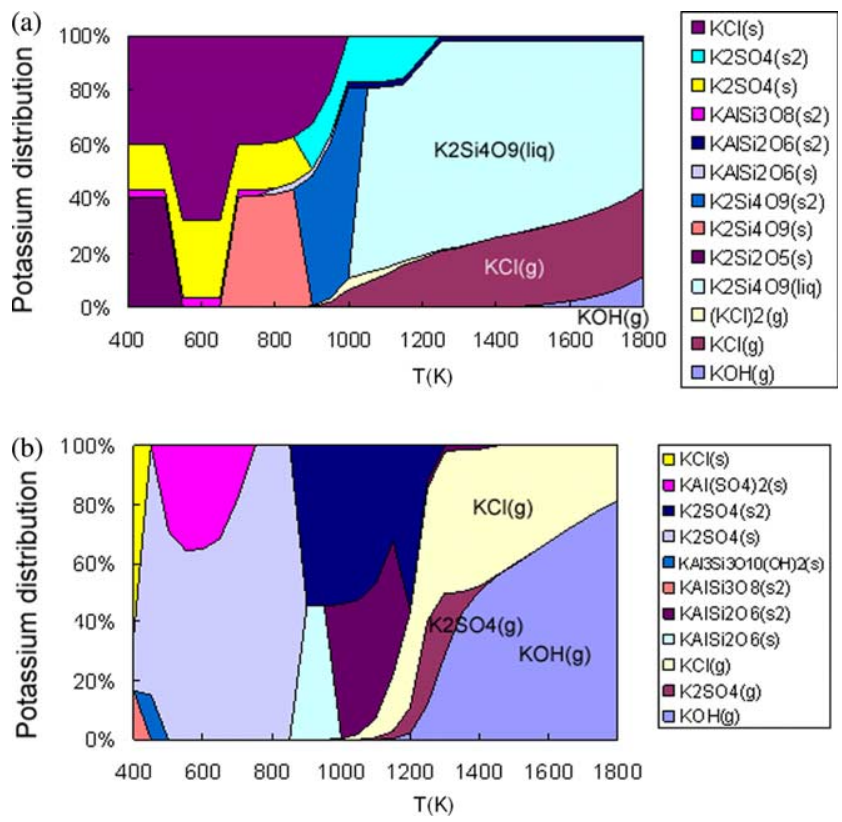

Fig. 2. Potassium behaviour during Danish straw and Swedish wood combustion $(\lambda=1.2, P=0.1 \mathrm{MPa})$.

and relatively high content of hydrogen (meaning that more hydroxyl radical may be produced), increasing temperature from 1300 to $1800 \mathrm{~K}$ might induce the conversion of $\mathrm{KCl}(\mathrm{g})$ to $\mathrm{KOH}(\mathrm{g})$ via the reaction:

$\mathrm{KCl}(\mathrm{g})+\mathrm{H}_{2} \mathrm{O} \Rightarrow \mathrm{KOH}(\mathrm{g})+\mathrm{HCl}(\mathrm{g})$

Therefore, at $1350 \mathrm{~K}, \mathrm{KCl}(\mathrm{g})$ begins to reduce and $\mathrm{HCl}(\mathrm{g})$ and $\mathrm{KOH}(\mathrm{g})$ to increase.

Due to the higher sodium content than potassium in sewage sludge, Fig. 3(c) shows the release behaviour of sodium and chlorine in sewage sludge combustion. Similar with the results in Fig. 3(b), all of the chlorine is released as $\mathrm{HCl}(\mathrm{g})$ in the temperature range of $800-1200 \mathrm{~K}$. Then increasing temperature from 1200 to $1800 \mathrm{~K}$ reduces the amount of released $\mathrm{HCl}(\mathrm{g})$, whereas $\mathrm{NaCl}(\mathrm{g})$ begins to form and gradually increases. At high temperature $(>1500 \mathrm{~K})$, $\mathrm{NaOH}(\mathrm{g})$ also occurs and significantly increases with increasing temperature.

Under combustion conditions shown in Fig. 3, the air excess coefficient $(\lambda)$ has less significant influence on the released amount of chlorine and potassium or sodium. For straw or sludge (except wood) combustion in Fig. 3(a) or (c), increasing air excess coefficient reduces the release of $\mathrm{HCl}(\mathrm{g})$ and increases the amount of $\mathrm{KCl}(\mathrm{g})$ or $\mathrm{NaCl}(\mathrm{g})$ in the high temperature range. Obviously, a lot of alkali metals may release from the condensed phase (e.g. liquid alkali silicate or solid aluminosilicate) and produce gaseous alkali chloride at high temperatures. Increasing the oxygen concentration in the flue gas might promote the reaction $\left(\mathrm{K}^{*}\right.$ denotes the radical potassium from

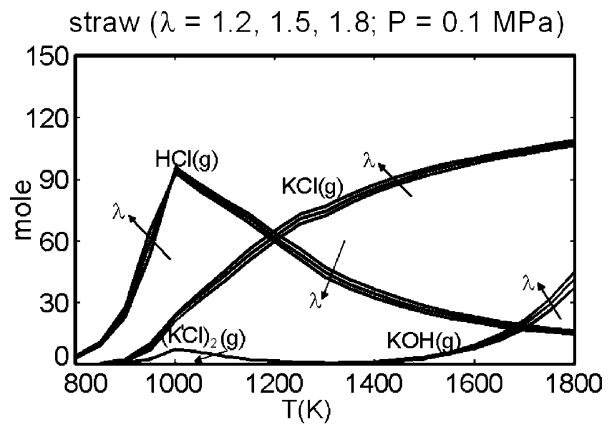

(a) Danish straw

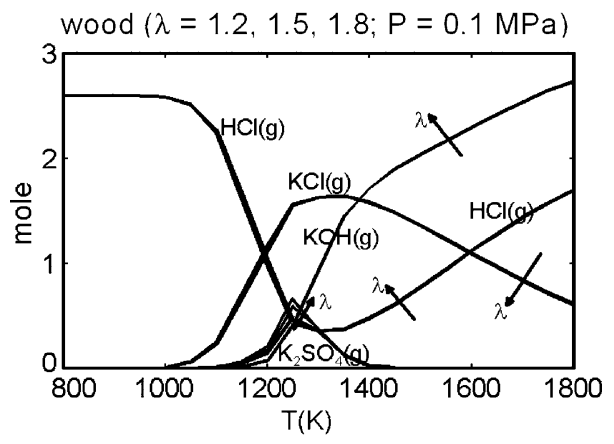

(b) Swedish wood

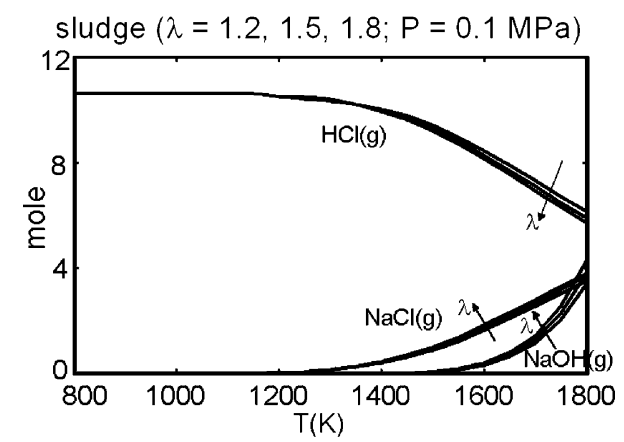

(c) Sewage sludge

Fig. 3. Release of chlorine and alkali metals in combustion with various air excess coefficients.

the condensed phase):

$\mathrm{K}^{*}+\mathrm{HCl}(\mathrm{g})+\mathrm{O} \Rightarrow \mathrm{KCl}(\mathrm{g})+\mathrm{OH}$

This increases the release of $\mathrm{KCl}(\mathrm{g})$. In addition, $\mathrm{KOH}(\mathrm{g})$ or $\mathrm{NaOH}(\mathrm{g})$ also increase with increasing air excess coefficient because of higher oxygen concentration in the gas phase.

Fig. 4 gives the release behaviour of chlorine and alkali metals in gasification with various air excess coefficients. Compared with Fig. 3, the air excess coefficient has significant influence on the released amount of chlorine, potassium or sodium under gasification conditions. For straw gasification in Fig. 4(a), increasing air excess coefficient from 0.2 to 0.8 increases the release of $\mathrm{HCl}(\mathrm{g})$ and reduces the formation of $\mathrm{KCl}(\mathrm{g})$.

For wood gasification in Fig. 4(b), $\mathrm{KCl}(\mathrm{s})$ directly vaporizes as $\mathrm{KCl}(\mathrm{g})$ in the temperature range of 


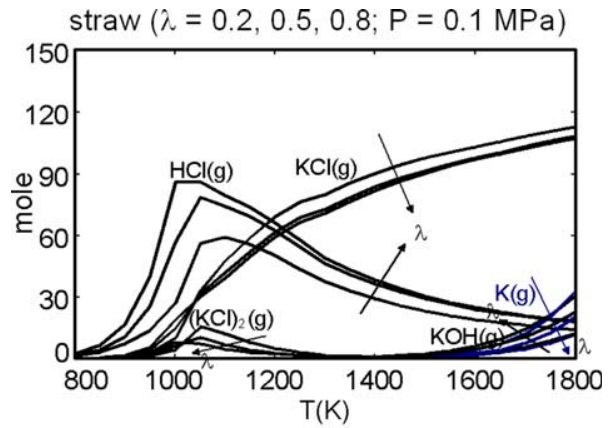

(a) Danish straw

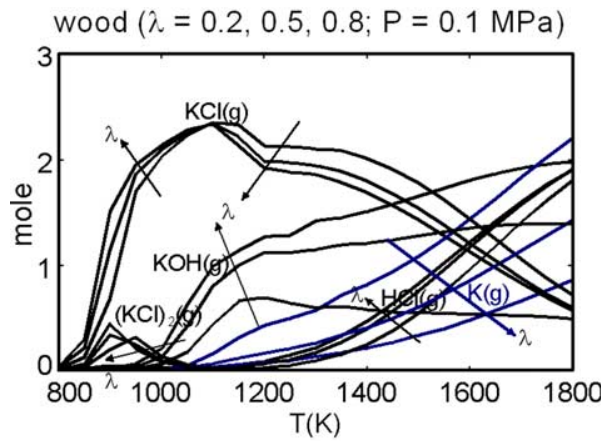

(b) Swedish wood

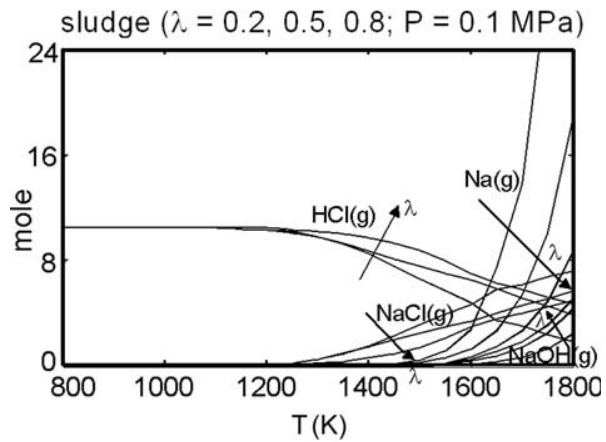

(c) Sewage sludge

Fig. 4. Release of chlorine and alkali metals in gasification with various air excess coefficients.

$800-1100 \mathrm{~K}$ and $\mathrm{KCl}(\mathrm{g})$ attains maximum at $1100 \mathrm{~K}$. Increasing temperature from 1000 to $1800 \mathrm{~K}$ enhances the release of $\mathrm{KOH}(\mathrm{g})$ and $\mathrm{K}(\mathrm{g})$. $\mathrm{HCl}(\mathrm{g})$ begins to occur at high temperatures $(>1100 \mathrm{~K})$ and increases sharply with temperature. At high temperatures $(>1100 \mathrm{~K})$, increasing air excess coefficient increases the release of $\mathrm{HCl}(\mathrm{g})$ and $\mathrm{KOH}(\mathrm{g})$ and reduces the formation of $\mathrm{KCl}(\mathrm{g})$ and $\mathrm{K}(\mathrm{g})$.

Under gasification conditions, increasing air excess coefficient increases the concentration of $\mathrm{H}_{2} \mathrm{O}$ and radical $\mathrm{OH}$ in the gas, and the reaction (1) is likely to promote the conversion of $\mathrm{KCl}(\mathrm{g})$ to $\mathrm{HCl}(\mathrm{g})$ and $\mathrm{KOH}(\mathrm{g})$. With increasing air excess coefficient, the decrease of $\mathrm{K}(\mathrm{g})$ and increase of $\mathrm{KOH}(\mathrm{g})$ might be explained by the reaction:

$\mathrm{K}(\mathrm{g})+\mathrm{OH} \Rightarrow \mathrm{KOH}(\mathrm{g})$
For sludge gasification, due to the higher sodium content than potassium, Fig. 4(c) shows the release behaviour of sodium and chlorine. Because the content of silicon and aluminium is high in sludge, sodium may retain in ash as aluminosilicate and is only likely to release at high temperatures $(>1300 \mathrm{~K})$. Increasing air excess coefficient increases the release of $\mathrm{HCl}(\mathrm{g})$ and $\mathrm{NaOH}(\mathrm{g})$ and reduces the formation of $\mathrm{NaCl}(\mathrm{g})$ and $\mathrm{Na}(\mathrm{g})$. This might be explained by the reactions:

$\mathrm{NaCl}(\mathrm{g})+\mathrm{H}_{2} \mathrm{O} \Rightarrow \mathrm{NaOH}(\mathrm{g})+\mathrm{HCl}(\mathrm{g})$

$\mathrm{Na}(\mathrm{g})+\mathrm{OH}(\mathrm{g}) \Rightarrow \mathrm{NaOH}(\mathrm{g})$

Fig. 5 describes the effect of pressure on the release of chlorine and alkali metals during biomass combustion. For straw combustion in Fig. 5(a), at mid-temperatures

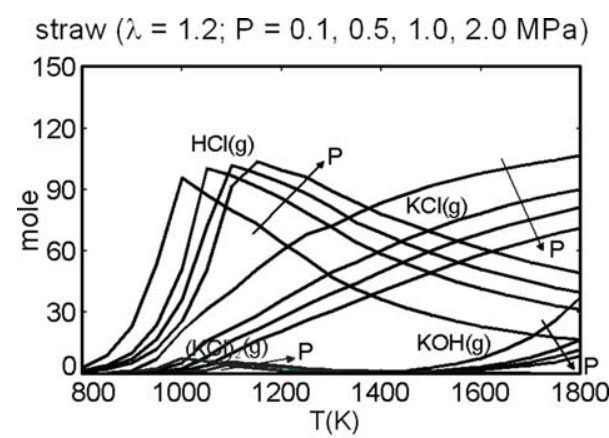

(a) Danish straw

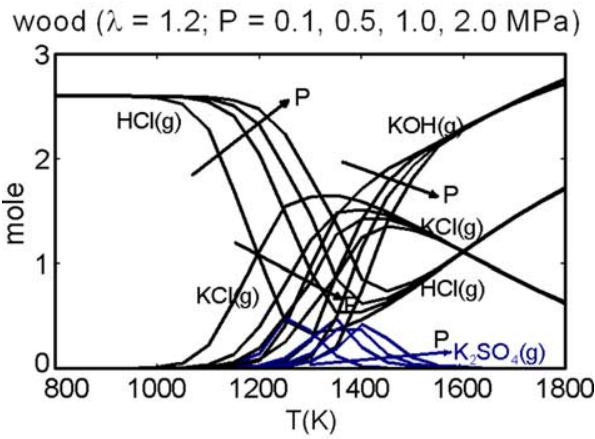

(b) Swedish wood

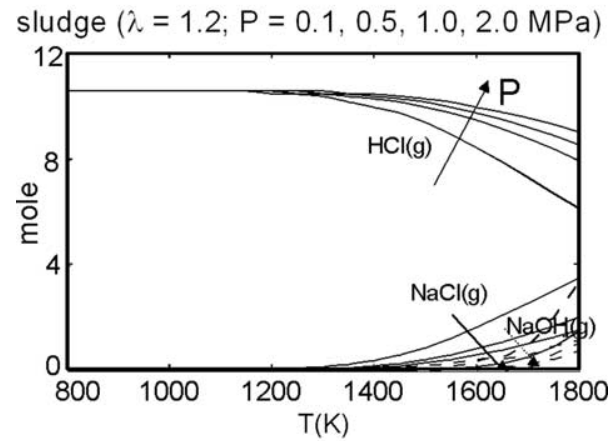

(c) Sewage sludge

Fig. 5. Release of chlorine and alkali metals in combustion with various pressures. 
(800-1100 K), increasing pressure postpones the release of $\mathrm{HCl}(\mathrm{g})$, but the maximum amount of $\mathrm{HCl}(\mathrm{g})$ increases. At high temperatures $(>1100 \mathrm{~K})$, increasing pressure significantly enhances the release of $\mathrm{HCl}(\mathrm{g})$, and thus reduces the formation of $\mathrm{KCl}(\mathrm{g})$ and $\mathrm{KOH}(\mathrm{g})$. For wood combustion in Fig. 5(b), it is interesting that the pressure only has an influence in the temperature range between 1100 and $1500 \mathrm{~K}$, thereby the pressure enhances the release of $\mathrm{HCl}(\mathrm{g})$ and decreases the formation of $\mathrm{KCl}(\mathrm{g})$ and $\mathrm{KOH}(\mathrm{g})$. For sludge combustion in Fig. 5(c), the influence of pressure only occurs in the temperature range above $1300 \mathrm{~K}$. Similar with the results of straw and wood combustion, the pressure enhances the release of $\mathrm{HCl}(\mathrm{g})$ and reduces the formation of $\mathrm{NaCl}(\mathrm{g})$ and $\mathrm{NaOH}(\mathrm{g})$.

Fig. 6 gives the effect of pressure on the release of chlorine and alkali metals during biomass gasification.

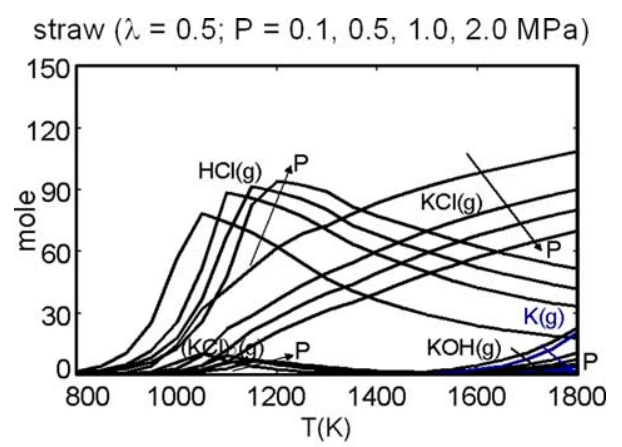

(a) Danish straw

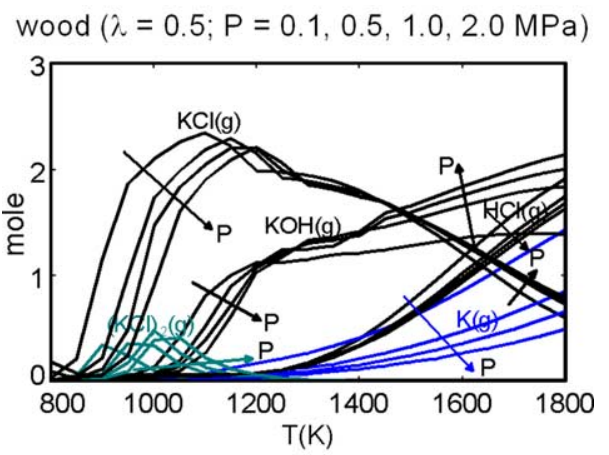

(b) swedish wood

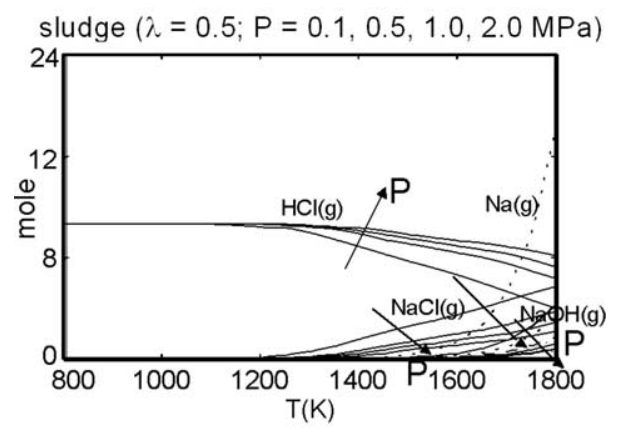

(c) Sewage sludge

Fig. 6. Release of chlorine and alkali metals in gasification with various pressures.
Results of straw or sludge gasification in Fig. 6(a) or (c) are similar with those in Fig. 5(a) or (c). At high temperatures $(>1200 \mathrm{~K})$, increasing pressure enhances the release of $\mathrm{HCl}(\mathrm{g})$, and thus reduces the formation of $\mathrm{KCl}(\mathrm{g}), \mathrm{NaCl}(\mathrm{g})$, $\mathrm{KOH}(\mathrm{g})$, or $\mathrm{NaOH}(\mathrm{g})$. In addition, the release of $\mathrm{K}(\mathrm{g})$ or $\mathrm{Na}(\mathrm{g})$ also decreases with increasing pressure. For wood gasification in Fig. 6(b), at mid-temperatures (800-1200 K), the pressure reduces the formation of $\mathrm{KCl}(\mathrm{g})$ and $\mathrm{KOH}(\mathrm{g})$. However, at high temperatures $(>1200 \mathrm{~K})$, the pressure enhances the formation of $\mathrm{KOH}(\mathrm{g})$ and $\mathrm{KCl}(\mathrm{g})$ and reduces the release of $\mathrm{K}(\mathrm{g})$ and $\mathrm{HCl}(\mathrm{g})$.

Figs. 7 and 8 indicate the effect of additional nitrogen on the release of chlorine and alkali metals during wood and sewage sludge pyrolysis. In the pyrolysis reactor, high temperature nitrogen is often used to heat the biomass and carry the pyrolysis gas, and thus it may have influence on the release of chlorine and alkali metals. At high temperatures ( $>1200 \mathrm{~K})$, Fig. 7 shows that nitrogen enhances the release of $\mathrm{HCl}(\mathrm{g})$ and reduces the amount of $\mathrm{KCl}(\mathrm{g})$ and $\mathrm{NaCl}(\mathrm{g})$. Increasing temperature significantly enhances the release of $\mathrm{K}(\mathrm{g})$ and $\mathrm{Na}(\mathrm{g})$. Nitrogen addition reduces the release of $\mathrm{K}(\mathrm{g})$ and $\mathrm{Na}(\mathrm{g})$, but causes a sharp increase of $\mathrm{KCN}(\mathrm{g})$ and $\mathrm{NaCN}(\mathrm{g})$. Due to the limited content of chlorine in sludge, Fig. 8 shows that nitrogen has less significant influence on the release of $\mathrm{HCl}(\mathrm{g}), \mathrm{KCl}(\mathrm{g})$, and $\mathrm{NaCl}(\mathrm{g})$. However, at very high temperatures $(>1500 \mathrm{~K})$, the amount of $\mathrm{K}(\mathrm{g})$, $\mathrm{Na}(\mathrm{g}), \mathrm{KCN}(\mathrm{g})$, and $\mathrm{NaCN}(\mathrm{g})$ significantly increases during

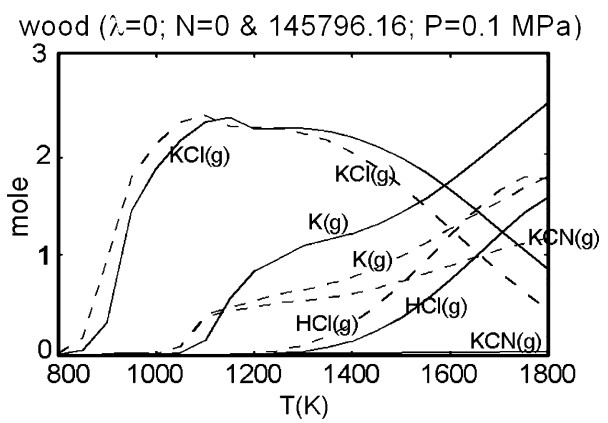

(a) Potassium

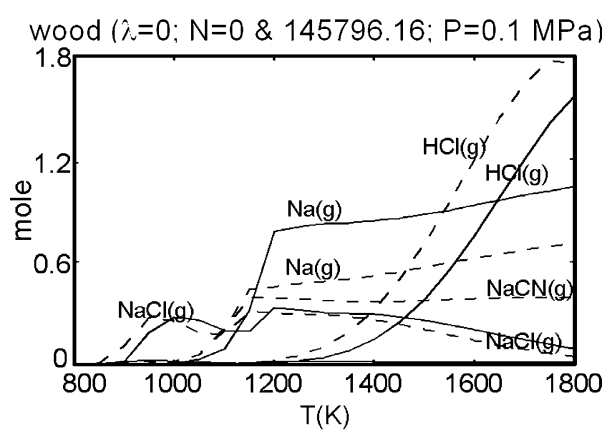

(b) Sodium

Fig. 7. Release of alkali metals during pyrolysis of Swedish wood in nitrogen environment. Solid line denotes the condition without additional nitrogen; dashed line denotes the condition with additional nitrogen. 


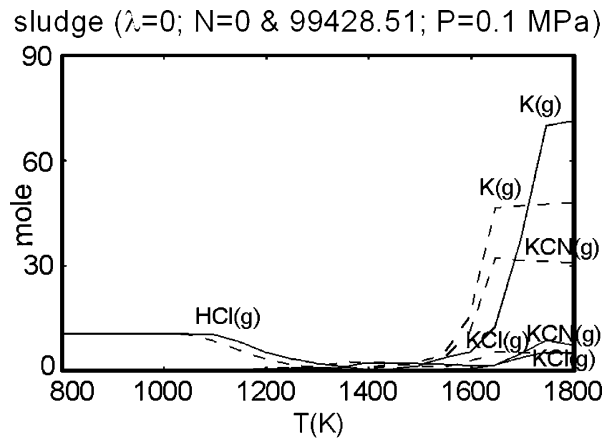

(a) Potassium

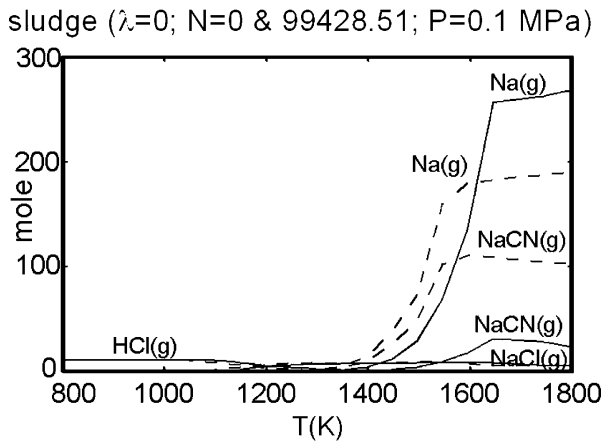

(b) Sodium

Fig. 8. Release of alkali metals during pyrolysis of sewage sludge in nitrogen environment. Solid line denotes the condition without additional nitrogen; dashed line denotes the condition with additional nitrogen.

sludge pyrolysis. Nitrogen addition also enhances the formation of $\mathrm{KCN}(\mathrm{g})$ and $\mathrm{NaCN}(\mathrm{g})$ and reduces the release of $\mathrm{K}(\mathrm{g})$ and $\mathrm{Na}(\mathrm{g})$.

In Fig. 9, kaolin is mixed with biomass to investigate the influence of aluminosilicate addition on the release of chlorine and alkali metals during straw combustion. In the fluidized bed reactor, kaolin may be contacted very well with biomass particle and thus lead to the decrease of the release of alkali metals [8]. Obviously, kaolin may enhance the formation of potassium aluminosilicate and retain potassium in ash. Increasing kaolin dosage significantly reduces the formation of $\mathrm{KCl}(\mathrm{g})$ and $\mathrm{KOH}(\mathrm{g})$ and increases the release of $\mathrm{HCl}(\mathrm{g})$.

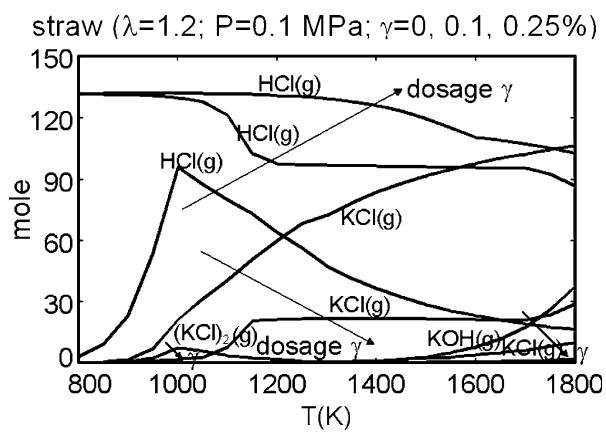

Fig. 9. Effect of kaolin addition on the behaviour of chlorine and alkali metals in combustion.

\section{Conclusions}

The chemical equilibrium calculation was used to investigate the release of chlorine and alkali metals during three sorts of biomass combustion or gasification under atmospheric or pressurized conditions. Results show that the main alkali containing species are $\mathrm{K}_{2} \mathrm{Si}_{4} \mathrm{O}_{9}(\mathrm{liq}), \mathrm{KCl}(\mathrm{g})$, and $\mathrm{KOH}(\mathrm{g})$ in straw combustion, and $\mathrm{KCl}(\mathrm{g}), \mathrm{K}_{2} \mathrm{SO}_{4}(\mathrm{~g})$, and $\mathrm{KOH}(\mathrm{g})$ in wood combustion, as well as $\mathrm{NaCl}(\mathrm{g})$ and $\mathrm{NaOH}(\mathrm{g})$ in sewage sludge combustion. Under combustion conditions, the air excess coefficient only has a limited influence on the release of chlorine and potassium or sodium. For straw or sludge combustion, increasing air excess coefficient reduces the release of $\mathrm{HCl}(\mathrm{g})$ and increases the formation of $\mathrm{KCl}(\mathrm{g})$ or $\mathrm{NaCl}(\mathrm{g})$ in the high temperature range.

Compared with the results in combustion, the air excess coefficient has significant influence on the release of chlorine, potassium or sodium during biomass gasification. At high temperatures $(>1100 \mathrm{~K})$, increasing air excess coefficient increases the release of $\mathrm{HCl}(\mathrm{g}), \mathrm{KOH}(\mathrm{g})$ or $\mathrm{NaOH}(\mathrm{g})$ as well as it reduces the formation of $\mathrm{KCl}(\mathrm{g})$, $\mathrm{NaCl}(\mathrm{g}), \mathrm{K}(\mathrm{g})$ or $\mathrm{Na}(\mathrm{g})$. Increasing air excess coefficient increases the concentration of $\mathrm{H}_{2} \mathrm{O}$ and radical $\mathrm{OH}$ in the gas, and this is likely to promote the following reactions:

$\mathrm{KCl}(\mathrm{g})+\mathrm{H}_{2} \mathrm{O} \Rightarrow \mathrm{KOH}(\mathrm{g})+\mathrm{HCl}(\mathrm{g})$

$\mathrm{K}(\mathrm{g})+\mathrm{OH} \Rightarrow \mathrm{KOH}(\mathrm{g})$

During biomass combustion, the pressure may enhance the release of $\mathrm{HCl}(\mathrm{g})$ and reduces the formation of $\mathrm{KCl}(\mathrm{g})$, $\mathrm{NaCl}(\mathrm{g}), \mathrm{KCl}(\mathrm{g})$, and $\mathrm{NaOH}(\mathrm{g})$ at high temperatures. During straw or sludge gasification, the pressure also enhances the release of $\mathrm{HCl}(\mathrm{g})$ and reduces the formation of $\mathrm{KCl}(\mathrm{g})$, $\mathrm{NaCl}(\mathrm{g}), \mathrm{KCl}(\mathrm{g})$, and $\mathrm{NaOH}(\mathrm{g})$ as well as $\mathrm{K}(\mathrm{g})$ and $\mathrm{Na}(\mathrm{g})$ at high temperatures. During wood gasification, at mid-temperatures (800-1200 K), the pressure reduces the formation of $\mathrm{KCl}(\mathrm{g})$ and $\mathrm{KOH}(\mathrm{g})$. However, the pressure enhances the formation of $\mathrm{KOH}(\mathrm{g})$ and $\mathrm{KCl}(\mathrm{g})$ and reduces the release of $\mathrm{K}(\mathrm{g})$ and $\mathrm{HCl}(\mathrm{g})$ at high temperatures $(>1200 \mathrm{~K})$.

During wood and sewage sludge pyrolysis, nitrogen addition enhances the formation of $\mathrm{KCN}(\mathrm{g})$ and $\mathrm{NaCN}(\mathrm{g})$ and reduces the release of $\mathrm{K}(\mathrm{g})$ and $\mathrm{Na}(\mathrm{g})$. Kaolin addition in straw combustion may enhance the formation of potassium aluminosilicate in ash. Increasing kaolin dosage significantly reduces the formation of $\mathrm{KCl}(\mathrm{g})$ and $\mathrm{KOH}(\mathrm{g})$ and increases the release of $\mathrm{HCl}(\mathrm{g})$.

\section{Acknowledgements}

This work was conducted at IVD, University of Stuttgart and finalized at IMech, CAS. Financial support by the Alexander von Humbold foundation and Chinese Natural Science Foundation (No. 50376068) is gratefully acknowledged. The authors would also like to thank Jörg Maier for his help on this work. 


\section{References}

[1] Baxter LL. Biomass Bioenergy 1993;4(2):85-102.

[2] Miles TR, Miles TR, Baxter LL, Bryers RW, Jenkins BM, Oden LL. Biomass Bioenergy 1996;10:125-38.

[3] Jensen PA, Stenholm M, Hald P. Energy Fuels 1997;11:1048-55.

[4] Heinzel T, Siegle V, Spliethoff H, Hein KRG. Fuel Process Technol 1998;54(1-3):109-25.

[5] Valmari T, Lind TM, Kauppinen EI, Sfiris G, Nilsson K, Maenhaut W. Energy Fuels 1999;13:390-5.

[6] Nielsen NP, Frandsen FJ, Dam-Johansen K, Baxter LL. Prog Energy Combust Sci 2000;26:283-98.

[7] Hansen LA, Nielsen HP, Frandsen FJ, Dam-Johansen K, Horlyck S, Karlsson A. Fuel Process Technol 2000;64(1-3):189-209.

[8] Coda B, Aho M, Berger R, Hein KRG. Energy Fuels 2001;15(3): 680-90.

[9] Robinson AL, Junker H, Baxter LL. Energy Fuels 2002;16(2): 343-55.

[10] Demirbas A. Energy Convers Manage 2003;44(9):1465-79.

[11] Turn SQ, Kinoshita CM, Ishimura DM, Zhou J, Hiraki TT, Masutani SM. J Inst Energy 1998;71(489):163-77.

[12] Cummer KR, Brown RC. Biomass Bioenergy 2002;23(2):113-28.

[13] Dayton DC, French RJ, Milne TA. Energy Fuels 1995;9(5):855-65.

[14] Olie K, Vermeulen PL, Hutzinger O. Chemosphere 1977;6:455-9.

[15] Karasek FW, Dickson LC. Science 1987;237:754-6.

[16] Dickson LC, Lenoir D, Hutzinger O. Environ Sci Technol 1992;26: 1822-8.

[17] Raghunathan K, Gullet BK. Environ Sci Technol 1996;30:1827-34.
[18] Addink R, Paulus R, Olie K. Environ Sci Technol 1996;30:2350-4.

[19] Frankenhaeuser M, Manninen H, Kojo I, Ruuskanen J, Vartiainen T, Vesterinen R, et al. Chemosphere 1993;27:309-16.

[20] Weber R, Hagenmaier H. Chemosphere 1999;38(3):529-49.

[21] Valmari T, Lind TM, Kauppinen EI, Sfiris G, Nilsson K, Maenhaut W. Energy Fuels 1999;13(2):379-89.

[22] Sherwood S. Science 2002;295(5558):1272-5.

[23] Boman C, Nordin A, Bostrom D, Ohman M. Energy Fuels 2004;18(2): $338-48$.

[24] Olsson JG, Jaglid U, Pettersson JBC, Hald P. Energy Fuels 1997; 11(4):779-84.

[25] Jensen A, Dam-Johansen K, Wójtowicz MA, Serio MA. Energy Fuels 1998;12:929-38.

[26] Dayton DC, Belle-Oudry D, Nordin A. Energy Fuels 1999;13(6): 1203-11.

[27] Hansen LA, Frandsen FJ, Dam-Johansen K, Sørensen HS, Skrifvars B-J. Energy Fuels 1999;13:803-16.

[28] Jensen PA, Frandsen FJ, Dam-Johansen K, Sander B. Energy Fuels 2000;14:1280-5.

[29] Wei XL, Lopez C, von Puttkamer T, Schnell U, Unterberger S, Hein KRG. Energy Fuels 2002;16(5):1095-108.

[30] Tran KQ, Iisa K, Hagstrom M, Steenari BM, Lindqvist O, Pettersson JBC. Fuel 2004;83(7-8):807-12.

[31] Steffin C, Wanzl W, van Heek KH. Proceedings of ninth international conference on coal science, Essen, Germany, 7-12 September 1997; p. 1055-8.

[32] Frandsen F, Dam-Johansen K, Rasmussen P. Prog Energy Combust Sci 1994;20:115-38. 